\title{
Genetic analysis for geographic isolation comparison of brown bears living in the periphery of the Western Carpathians Mountains with bears living in other areas
}

\author{
Ján Graban $^{{ }^{*}}$, Jana Kisková ${ }^{1}$, Pavol Pepich ${ }^{2}$, Robin Rigg ${ }^{3}$ \\ ${ }^{1}$ Institute of the High Mountain Biology, University of Žilina Tatranská Javorina, Tatranská Javorina, Slovak Republic \\ ${ }^{2}$ Institute of Foreign Languages, University of Žilina, Žilina, Slovak Republic \\ ${ }^{3}$ Slovak Wildlife Society, Liptovský Hrádok, Slovak Republic \\ Email: "graban@uniza.sk
}

Received 24 April 2013; revised 26 May 2013; accepted 10 June 2013

Copyright (C) 2013 Ján Graban et al. This is an open access article distributed under the Creative Commons Attribution License, which permits unrestricted use, distribution, and reproduction in any medium, provided the original work is properly cited.

\section{ABSTRACT}

Populations of the European brown bear (Ursus arctos L.) differ substantially in size, degree of geographic isolation and level of genetic diversity. Present patterns result from phylogeographic processes and profound human intervention. We assessed the genetic variability of a subpopulation of brown bears near the periphery of their range in the Western Carpathian Mountains and compared their genetic properties with those of bears in the core of the same population and elsewhere. Samples were collected non-invasively in 2007-2008 and 2010 in Strážovské Vrchy Protected Landscape Area (PLA) in Slovakia (included in the NATURA 2000 networking programme). Seven polymorphic microsatellite loci (UaMU26, UaMU64, G10B, G1D, G10L, UaMU50 and UaMU51) were amplified using a nested PCR in order to assess the following parameters: variability, allelic combinations, heterozygosity, number of alleles and inbreeding coefficient. Sufficient brown bear DNA for analysis was obtained from 57 out of 140 samples (41\%), among which 45 different genotypes were identified. Loci had a mean of $2.71 \pm 0.76$ alleles. Average observed heterozygosity was 0.59 . The inbreeding coefficient was negative for all but one of the analysed loci (2007-2008). In the year 2010 was negative three of seven loci. These results imply that gene flow with other parts of the population has been maintained in the reduced level and the isolation level of bears in the study area was not so low. Nevertheless, the genetic variability of bears in Strážovské Vrchy PLA was lower than that reported from other localities in the Carpathian Mountains. The results are discussed in the context of behavioural ecology

${ }^{*}$ Corresponding author. and conservation genetics.

Keywords: Carpathian Mountains; European Brown Bear; Ursus arctos L.; Genetic Diversity; Microsatellite Markers; Non-Invasive Sampling

\section{INTRODUCTION}

The brown bear (Ursus arctos) re-colonised the entire European continent after the Last Glacial Maximum $[1,2]$, and yet its current distribution shows a discontinuous pattern as a result of various human activities $[3,4]$. In contrast to the relatively large and contiguous populations with higher expected heterozygosity and allelic diversity in Eastern Europe, the Balkans and Scandinavia [5] population fragments in the western part of the continent are extremely small and isolated, with low levels of genetic variability and vulnerable to genetic drift and inbreeding [6-8].

An additional level of complexity is added by the existence of three mitochondrial subclades $[6,9,10]$. They may be the result of different founder populations having passed through bottlenecks prior to rapid recolonisation during the Holocene [11] or recent human-induced population fragmentation due to habitat loss and killing [12,13].

It has been suggested that one of the glacial refugia from which brown bears of the eastern lineage (subclade 3a) re-colonised most of continental Eurasia was in the Western Carpathian Mountains of present day Slovakia $[2,11,14]$. Alternatively, bears may have survived the glacial period in the cold tundra-steppe of central Europe [12]. Regardless of when and how they arrived, brown bears persisted in the Western Carpathians in a large, continuous population until the Middle Ages [15] and in most forested upland areas of present-day Slovakia 
through to the 19th century [16]. Deforestation, overhunting and eradication programmes then precipitated a catastrophic decline in range and numbers culminating in the 1930s, when it was estimated that only c. 20 - 60 individuals remained in an isolated, relict population [16].

A 30-year moratorium on hunting facilitated population recovery [17]. The bears continued to increase in number and reoccupy parts of their former range despite the resumption of limited hunting from the 1960s [18]. The Western Carpathian bear population now numbers several hundred individuals and extends across all mountain ranges of central and northern Slovakia [19]. However, although it was thought that connection with the much larger Eastern Carpathian population was re-established in the 1980s [20], the two populations show a high degree of differentiation most likely resulting from genetic divergence during the c.100 years of their division and evidence of renewed gene flow is sparse [21].

Populations that have passed through a recent demographic bottleneck would generally be expected to have lost genetic diversity through stochastic drift [22]. However, medium-high levels of allelic variation have been found in the nuclear DNA of Western Carpathian bears and their level of genetic diversity seems to be within the range commonly observed in different populations of brown bears and other mammals [15,21,23], which suggests the population bottleneck may not have been quite so severe as feared by contemporary observers. The main aim of our study was to examine the degree of genetic diversity and geographic isolation of bears in a subpopulation near the periphery of their current distribution in the Western Carpathians and compare it with that of bears in core areas of the population and in select European subpopulations.

Fieldwork was conducted in the Strážovské vrchy mountain range $\left(49^{\circ} 23^{\prime} 702^{\prime \prime} \mathrm{N}, 18^{\circ} 73^{\prime} 46^{\prime \prime} \mathrm{E}\right)$, which extends over an area of c. $900 \mathrm{~km}^{2}$ in northwest Slovakia (Figure 1) and forms part of the Inner Western Carpathian Mountains. Brown bears were apparently absent until the mid 1960s [17,19] but re-colonised during the period 1967-1984, when the recovering Western Carpathian bear population expanded its range $40 \mathrm{~km}$ northwestwards [24].

Intense development in molecular technology, have moved bear ecology into a significant development in which genetic analyses can be performed with ease and with great informative value. Environmentalists can now routinely utilize genetic information obtained from DNA to formulate questions about the behavioural ecology and conservation genetics of bear populations. The highly variable microsatellites markers that have been analysed in this study offer an effective tool for individual identification. These DNA fingerprints can be used in an ecological context for the dendrogram construction based on the degree of microsatellite profiles similarity to linking individuals. Then we can get a view on the degree of genetic relatedness of individuals grouped into clusters. Implementation of population genetic features of the PLA Strážovské vrchy provides an overview of the migration rate between neighboring populations of the brown bears.

\section{MATERIAL AND METHODS}

\subsection{Sample Collection and DNA Isolation}

A total of samples $57(41.8 \%)$ out 140 from different sites of Strazovske vrchy Mts were collected. A 37 samples collected during the year 2010 (faeces and hair samples) and 20 samples from Strazovske vrchy territory (during the period 2007-2008) were examined. Sufficient brown bear DNA for analysis was obtained from 20 (2007-2008) out of 46 samples and 37 (2010) out of 94 samples collected in the field. A total of 45 different genotypes were identified among 28 samples from faeces and 29 from hair.

DNA extraction from hairs was performed using $10 \%$ Chelex according to Kruckenhauser et al. [25], Depending on availability and quality hairs with visible roots were used, DNA extractions from non-invasive samples were performed with the QIAamp DNA Stool Kit (QIAGEN) with a final elution volume of $100 \mu 1$.

Samples were collected in the Strážovské Vrchy Protected Landscape Area (Figure 1). The PLA covers c. 300 $\mathrm{km} 2$ of which $78 \%$ is forest and $19 \%$ agricultural land. Altitude ranges from 315 to $1213 \mathrm{~m}$ a.s.l. On the basis of annual track surveys, opportunistic direct observations and camera trapping we estimated there to be approximately 20 different bears using the area, although some of them may have had home ranges extending beyond the study area.

\subsection{Microsatellites Analysis and Gender Identification}

Seven microsatellite loci Mu26, Mu64, G10B, G1D, G10L, Mu50 and Mu51 were amplified using poly-

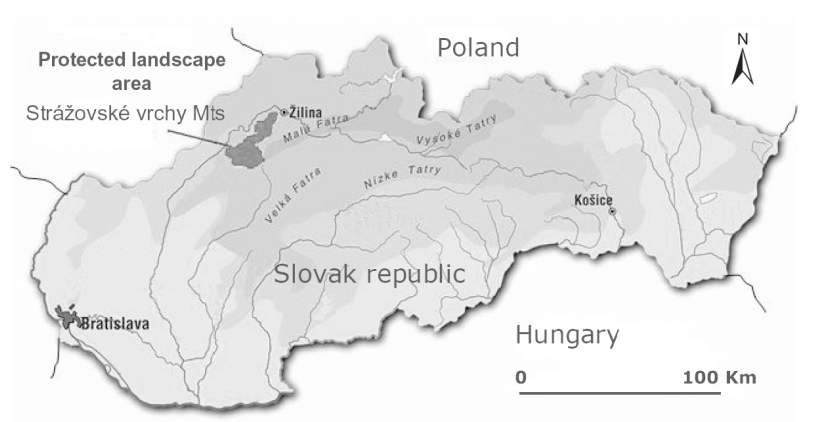

Figure 1. Location of the study area in relation to the distribution of the Western Carpathian population of brown bears. 
merase chain reaction [7] and fragment length (allele) analyses were carried out on eight-capillary sequencer (Genome Lab GeXP, BeckmanCoulter). Analyses were repeated in order to verify the reliability of individual allele length determination.

Molecular sexing of the bears identified by DNA fingerprinting was assessed by amplification of the Sry fragment on theY chromosome [26]. In each cell, the autosomal microsatellite locus is twice as concentrated as the Sry gene. PCR products were checked on $2.0 \%$ agarose gels. Males show two bands, the microsatellite and Sry fragment, while females show only the ZFY/ZFX band. The primer pair used for gender determination is not bear-specific, but amplifies the Sry fragment in a wide variety of mammals, including humans [26]. To avoid contamination PCR reactions were set up by a female investigator.

DNA was extracted from hair using 10\% Chelex solution [25] and from faeces with the Qiamp DNA Stool ${ }^{\circledR}$ kit (Qiagen). To test for individuals, seven microsatellite loci (UaMU26, UaMU64, G10B, G1D, G10L, UaMU50 and UaMU51) were amplified in a nested polymerase chain reaction (PCR) [7]: a longer fragment of each locus was amplified prior to amplifying a more specific area. Two-step PCR procedures improve genotyping success rate and limit genotyping errors [27].

Observed (HO) and expected (HE) heterozygosity were calculated using Cervus 3.0 software (Field Genetics). Results were compared with genetic data from brown bears in core ranges of the Carpathian Mountains in Slovakia [21,28] and Romania [21] as well as in central Austria [25].

\subsection{Statistical Methods}

Observed (HO) and expected (HE) heterozygosity were calculated with CERVUS software. Descriptive statistics for each locus (mean number of alleles per locus, heterozygosities and polymorphic information content (PIC) were computed from allele frequencies. The Fisher's exact test was used to check for genotypic linkage disequilibrium for all pairs of loci by employing the Markov chain method, as implemented in GENEPOP [29]. Deviations from Hardy-Weinberg (HW) proportions were evaluated through the Weir and Cockerham's [30] and Robertson and Hill's [31] estimates of FIS to test for heterozygote deficit with Levene's correction for small sample size, using the method described by Guo and Thompson [32].

The difference between Hardy-Weinberg heterozygosity $(H E)$ and that expected from the observed number of alleles (HEQ) was tested under the assumption of mutation-drift equilibrium, given the sample size. Evidence for a recent reduction of population size is assumed when HE is significantly higher than HEQ. The patterns of microsatellite mutations appear to be extremely complex [33] and the evolution mode of bear microsatellite loci was not known. Therefore, calculations were made according to three models: the Infinite Alleles Mode [34], the strict Stepwise Mutation Model [34] and the Two Phase Model (TPM) with a 5\% of multi-step changes: [35] Valdes, Slatkin and Freimer [36], an offshoot of the SMM, which accounts for addition or deletion of more than one repeat unit.

The loci screened in our study were evaluated for their reliability and resolving power when performing parentage tests. A simulation of parentage analysis was conducted using CERVUS version 2.0 [37]. That programme uses allele frequencies from the study population to run simulations of paternity inference when multiple males are non-excluded, allowing for user-defined inputs, such as the number of males that are candidates for paternity, the proportion of candidate males that are sampled and errors in genotyping. Success rates of parentage tests were derived assuming HW equilibrium in cases where one true parent was known and in cases where neither parent is known a priori, with 80 and $95 \%$ confidence levels. The simulations (10 000 repetitions) were conducted by changing parameters, e.g. the proportion of loci typed, the number of candidate parents, the fraction of candidates sampled and the level of potential laboratory mistyping.

\subsection{Division of Animals into Clusters}

Processing of acquired data and in particular in finding answers to the question of individuals distribution on the site led them to propose procedures for evaluation of microsatellite data was processed using our original software (Java script) (will be published in Oecologia Montana). Two methods were used Neighbor-joining and UPGMA (Unweighted Pair Group Method with Arithmetic Mean) for construction of clusters graphic presentation based on microsatellites data processing (Figure 2).

Neighbor-joining method provides not only the topology but also the branch lengths of the final tree. A pair of "neighbors" is a pair of animals connected through a single interior node in an unrooted, bifurcating tree [38].

UPGMA is a simple agglomerative or hierarchical clustering method often used for the creation of phenetic trees (phenograms). UPGMA assumes a constant rate of similarity between animals. UPGMA was initially designed for use in protein electrophoresis studies, but is currently most often used to produce guide trees for more sophisticated phylogenetic reconstruction algorithms.

The mean observed heterozygosity $\left(\mathrm{H}_{\mathrm{O}}\right)$ among the seven loci examined in the year 2007-2008 was 0.70 and 0.53 in the year 2010 , the mean expected heterozygosity $\left(\mathrm{H}_{\mathrm{E}}\right) 0.54$ in the year 2007-2008 and 0.57 in the year 
(a)

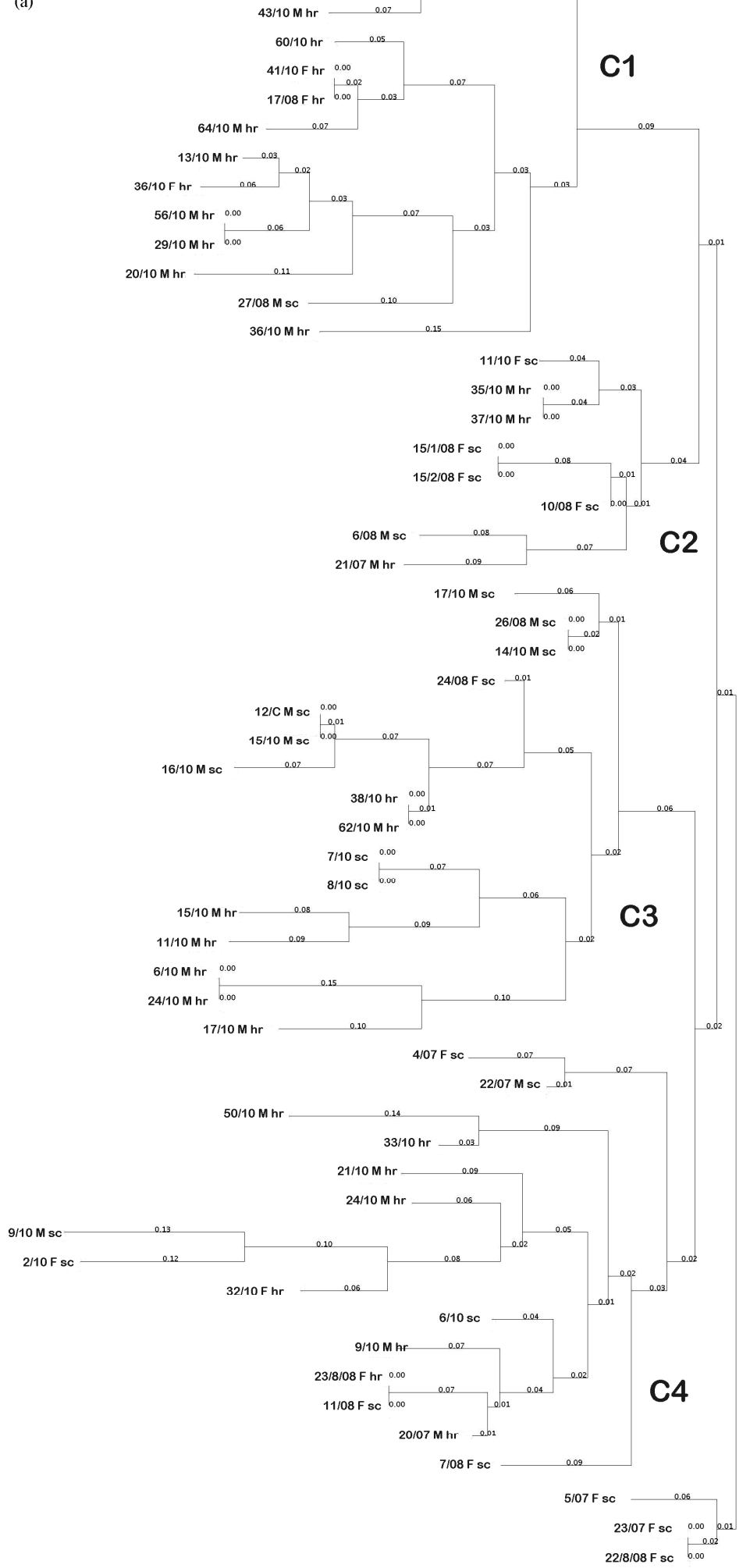



Figure 2. Schematic presentation of animals distribution into "family" clusters (C1 - C4) based on degree of relatedness between individual microsatellite profiles. (a) present Neighbor-joining method and (b) the UPGMA method (hr-hair samples, sc—scat samples). 
2010. Only one locus (UaMU26) had a $\mathrm{H}_{\mathrm{O}}$ lower than $\mathrm{H}_{\mathrm{E}}$ in the year 2007-2008. In the year 2010 it was locus UaMU26, UaMU64, G10B and Ua MU50 (Table 1). Locus G1D had the most alleles (four), while UaMU26, G10B and G10L showed low allelic variability (two alleles per locus). With the exception of G10L in the year 2007-2008 and UaMU64 in the year 2010, the observed number of alleles at each locus $\left(n_{a}\right)$ was greater than the effective number of alleles $\left(\mathrm{n}_{\mathrm{e}}\right)$. The inbreeding coefficient was negative for six out of the seven loci (mean value $\left.\mathrm{F}_{\mathrm{IS}}=-0.27\right)$, the exception being UaMU26 $\left(\mathrm{F}_{\mathrm{IS}}=\right.$ $+0.33)(2007-2008)$. In the year 2010 the inbreeding coefficient was negative only for three out seven loci (mean value $\mathrm{F}_{\mathrm{IS}}=0.08$ ).

Table 1. Genetic variability of brown bears in the Strážovské Vrchy Mountains, Slovakia. $n_{a}$ - observed number of alleles, $n_{e}-e f f e c-$ tive number of alleles, $\mathrm{P}_{\mathrm{IC}}$-Polymorphic information content, $\mathrm{H}_{\mathrm{O}}$ - observed heterozygosity, $\mathrm{H}_{\mathrm{E}}$ - expected heterozygosity, $\mathrm{F}_{\mathrm{IS}}-$ inbreeding coefficient.

(a)

\begin{tabular}{ccccccc}
\hline & \multicolumn{3}{c}{$2007-2008$} & & & \\
\hline Locus & $\mathrm{n}_{\mathrm{a}}$ & $\mathrm{n}_{\mathrm{e}}$ & $\mathrm{P}_{\mathrm{IC}}$ & $\mathrm{H}_{\mathrm{O}}$ & $\mathrm{H}_{\mathrm{E}}$ & $\mathrm{F}_{\mathrm{IS}}$ \\
\hline UaMU26 & 2 & 1.89 & 0.35 & 0.30 & 0.47 & 0.36 \\
UaMU64 & 3 & 2.38 & 0.47 & 0.85 & 0.58 & -0.47 \\
G10B & 2 & 1.49 & 0.27 & 0.40 & 0.33 & -0.21 \\
G1D & 4 & 3.03 & 0.59 & 0.85 & 0.67 & -0.27 \\
G10L & 2 & 2.04 & 0.38 & 0.80 & 0.51 & -0.57 \\
UaMU50 & 3 & 2.56 & 0.51 & 0.80 & 0.61 & -0.31 \\
UaMU51 & 3 & 2.63 & 0.53 & 0.90 & 0.62 & -0.45 \\
Mean & 2.71 & 2.29 & 0.44 & 0.70 & 0.54 & -0.27 \\
St. Dev & 0.76 & 0.52 & 0.10 & 0.12 & & 0.31 \\
\hline
\end{tabular}

(b)

\begin{tabular}{ccccccc}
\hline & & & 2010 & & & \\
\hline Locus & $\mathrm{n}_{\mathrm{a}}$ & $\mathrm{n}_{\mathrm{e}}$ & $\mathrm{P}_{\mathrm{IC}}$ & $\mathrm{H}_{\mathrm{O}}$ & $\mathrm{H}_{\mathrm{E}}$ & $\mathrm{F}_{\mathrm{IS}}$ \\
\hline UaMU26 & 2 & 1.89 & 0.35 & 0.07 & 0.47 & 0.85 \\
UaMU64 & 3 & 3.13 & 0.59 & 0.54 & 0.68 & 0.21 \\
G10B & 2 & 1.96 & 0.37 & 0.32 & 0.49 & 0.35 \\
G1D & 4 & 3.33 & 0.64 & 0.79 & 0.70 & -0.13 \\
G10L & 2 & 1.92 & 0.36 & 0.75 & 0.48 & -0.56 \\
UaMU50 & 3 & 2.50 & 0.51 & 0.50 & 0.75 & 0.17 \\
UaMU51 & 3 & 2.27 & 0.48 & 0.56 & 0.57 & 0.34 \\
Mean & 2.71 & 2.43 & 0.47 & 0.10 & 0.08 & 0.47 \\
St. Dev & 0.76 & 0.59 & 0.12 & & & 0.17 \\
\hline
\end{tabular}

(c)

\begin{tabular}{|c|c|c|c|c|c|c|}
\hline \multicolumn{7}{|c|}{$2007-2010$} \\
\hline Locus & $\mathrm{n}_{\mathrm{a}}$ & $\mathrm{n}_{\mathrm{e}}$ & $\mathrm{P}_{\mathrm{IC}}$ & $\mathrm{H}_{\mathrm{O}}$ & $\mathrm{H}_{\mathrm{E}}$ & $\mathrm{F}_{\text {IS }}$ \\
\hline UaMU26 & 2 & 2 & 0.38 & 0.14 & 0.50 & 0.72 \\
\hline UaMU64 & 3 & 2.94 & 0.58 & 0.67 & 0.66 & -0.02 \\
\hline G10B & 2 & 1.96 & 0.37 & 0.35 & 0.49 & 0.29 \\
\hline G1D & 4 & 3.33 & 0.64 & 0.81 & 0.70 & -0.16 \\
\hline G10L & 2 & 2 & 0.37 & 0.81 & 0.50 & -0.62 \\
\hline UaMU50 & 3 & 2.44 & 0.50 & 0.61 & 0.59 & -0.04 \\
\hline UaMU51 & 3 & 2.27 & 0.48 & 0.77 & 0.56 & -0.38 \\
\hline Mean & 2.71 & 2,42 & 0.47 & 0.59 & 0.57 & -0.03 \\
\hline St. Dev & 0.76 & 0.53 & 0.11 & 0.26 & 0.08 & 0.44 \\
\hline
\end{tabular}


Locus UaMU26, UaMU64, G1D, G10L, UaMU50 andUaMU51 had the equal number of different allelic combinations (three) (Table 2). The least variability was found at loci G10B ( 2 alleles per locus in 2 different combinations) (2007-2008).

Locus UaMU64 and UaMU50 had the equal number of different allelic combinations (four), followed by UaMU26, G1D, G10B and UaMU51 with three each. The least variability was found at loci G10L (2 alleles per locus in 2 different combinations) (2010).

\section{DISCUSSION AND CONCLUSIONS}

The brown bear is a wide-ranging species exhibiting male-biased dispersal [39]. Adult males commonly use hundreds of square kilometres in their search for food and mating opportunities and dispersing subadult male brown bears may roam over areas up to $12,000 \mathrm{~km}^{2}$ [1]. Such movements facilitate gene flow and, in the case of dispersing young males, there is evidence that it operates as a mechanism to avoid inbreeding [39]. The relatively high level of heterozygosity and low degree of inbreeding we found in bears in Strážovské vrchy (this study) suggests that the subpopulation is not geographically isolated and gene exchange with other segments of the population has been maintained.

The most obvious potential source of migration into the study area is the Malá Fatra mountain range, which lies immediately to the east (Figure 1) and has a high density of bears $[19,28]$. The eastern edge of the Strážovské vrchy seems to present the least obstruction to wildlife movement in and out of the study area, as the unfenced primary road I/64 passes through a heavily forested landscape for the $20-\mathrm{km}$ section between Rajecká Lesná and Klačno, forest availability being the most important habitat constraint on bear distribution in the Western Carpathians [40]. There are, however, several other nearby ranges from which bears could reasonably be expected to reach Strážovské vrchy, including Vtáčnik, Kremnické vrchy and Vel'ká Fatra.

To elucidate their movements without the need to live-trap, immobilise and fit animals with telemetry equipment, DNA profiling or 'genetic fingerprinting' in combination with GPS localisation of sampling sites enables individuals to be identified and tracked non-invasively $[7,28]$. This may help to identify important biocorridors in need of protection or improvement $[41,42]$. Effective immigration can also be estimated from changes in observed and expected heterozygosity and heterozygote excess $[13,43,44]$.

Although the results of the present study showed relatively high variability (increasing in the year 2010), microsatellite analysis of brown bears in Malá Fatra National Park [28] found higher numbers of alleles per locus (Table 3). Moreover, the difference between observed and expected heterozygosity was greater in Malá Fatra than in Strážovské vrchy and low values of FIS for each locus demonstrated a higher occurrence of heterozygotes. Higher variability has also been found in central Slovakia, northern Slovakia and Romania [21].

The leading edge of an expanding population might be expected to become less diverse as a result of a series of genetic bottlenecks [22]. However, two loci analysed in the small central Austrian bear population [25] showed a similar level of variability to that found in Malá Fatra and central Slovakia, even though all genotyped individuals were descended from just four founders. These four individuals arrived in the area $20-40$ years ago, which is more recently than bears re-colonised the Strážovské vrchy, and there is no evidence of there having been any subsequent immigration.

The founders of the central Austrian bear population

Table 2. Allelic combinations found at seven microsatellite loci in genomic DNA from brown bears in the Strážovské Vrchy Mountains. Slovakia. The most frequently occurring combination for each locus is shown in bold. AC—allelic combinations detected.

(a)

\begin{tabular}{cccccccc}
\hline \multicolumn{1}{c}{$2007-2008$} \\
\hline AC & UaMU26 & UaMU64 & G10B & G1D & G10L & UaMU50 & UaMU51 \\
\hline 1 & $\mathbf{1 8 2 / 1 8 2}$ & $177 / 194$ & $\mathbf{1 1 4 / 1 1 4}$ & $171 / 221$ & $143 / 143$ & $\mathbf{1 1 8 / 1 2 1}$ & $110 / 110$ \\
2 & $182 / 198$ & $\mathbf{1 8 4 / 1 9 4}$ & $114 / 126$ & $179 / 179$ & $\mathbf{1 4 3 / 1 7 1}$ & $121 / 125$ & $\mathbf{1 1 0 / 1 3 6}$ \\
3 & $198 / 198$ & $184 / 184$ & & $\mathbf{1 7 9 / 2 0 8}$ & $171 / 171$ & $125 / 125$ & $110 / 116$ \\
\hline
\end{tabular}

(b)

\begin{tabular}{cccccccc}
\hline \multicolumn{1}{c}{2010} \\
\hline AC & UaMU26 & UaMU64 & G10B & G1D & G10L & UaMU50 & UaMU51 \\
\hline 1 & $\mathbf{1 8 2 / 1 8 2}$ & $177 / 177$ & $\mathbf{1 1 4 / 1 1 4}$ & $171 / 221$ & $143 / 143$ & $118 / 121$ & $110 / 110$ \\
2 & $182 / 198$ & $177 / 194$ & $114 / 126$ & $179 / 179$ & $\mathbf{1 4 3 / 1 7 1}$ & $\mathbf{1 2 1 / 1 2 1}$ & $\mathbf{1 1 0 / 1 3 6}$ \\
3 & $198 / 198$ & $\mathbf{1 8 4 / 1 9 4}$ & $126 / 126$ & $\mathbf{1 7 9 / 2 0 8}$ & & $121 / 125$ & $110 / 116$ \\
4 & & $184 / 184$ & & & & $125 / 125$ & \\
\hline
\end{tabular}


Table 3. The selected Carpatian Mts and central Austria Brown bear subpopulations genetic variability comparison. $\mathrm{n}_{\mathrm{a}}-\mathrm{ob}-$ served number of alleles, $\mathrm{H}_{\mathrm{O}}$-observed heterozygosity, $\mathrm{H}_{\mathrm{E}}-$ expected heterozygosity, $\mathrm{F}_{\mathrm{IS}}$ - inbreeding coefficient of Small Fatra [28]—SF, Northern Slovakia [21]—NS, Central Slovakia [21] — CS, Central Austria [25] — CA and Romania [21]—R.

\begin{tabular}{ccccc}
\hline Locality and locus & $\mathrm{n}_{\mathrm{a}}$ & $\mathrm{H}_{\mathrm{O}}$ & $\mathrm{H}_{\mathrm{E}}$ & $\mathrm{F}_{\mathrm{IS}}$ \\
\hline SF-UaMU26 & 4 & 0.65 & 0.44 & -0.48 \\
CA-UaMU26 & 4 & 0.65 & 0.57 & -0.13 \\
SF-UaMU64 & 9 & 0.74 & 0.46 & -0.61 \\
NS-G10B & 5 & 0.59 & 0.63 & 0.06 \\
CS-G10B & 4 & 0.60 & 0.63 & 0.05 \\
CA-G10B & 4 & 1 & 0.69 & -0.45 \\
R-G10B & 8 & 0.76 & 0.75 & -0.01 \\
SF-G1D & 4 & 0.63 & 0.43 & -0.47 \\
NS-G1D & 6 & 0.68 & 0.79 & 0.14 \\
CS-G1D & 6 & 0.76 & 0.76 & 0.00 \\
R-G1D & 7 & 0.71 & 0.73 & 0.03 \\
NS-G10L & 6 & 0.41 & 0.48 & 0.16 \\
CS-G10L & 6 & 0.60 & 0.61 & 0.02 \\
R-G10L & 8 & 0.79 & 0.84 & 0.06 \\
NS-UaMU50 & 6 & 0.76 & 0.75 & -0.01 \\
CS-UaMU50 & 6 & 0.72 & 0.65 & -0.11 \\
R-UaMU50 & 8 & 0.80 & 0.82 & 0.02 \\
NS-UaMU51 & 6 & 0.52 & 0.74 & 0.30 \\
CS-UaMU51 & 7 & 0.73 & 0.82 & 0.11 \\
R-UaMU51 & 7 & 0.72 & 0.78 & 0.08 \\
\hline
\end{tabular}

originated in Slovenia and are therefore part of the western lineage (subclade 1b), whereas Slovakia's bears belong to the eastern lineage known as subclade 3a [45]. There are bears of both mtDNA lineages in Romania [5] but the differentiation is not reflected in nuclear loci, perhaps due to male-mediated gene flow and female philopatry [21]. The genetic diversity of brown bears is highest in Romania [46], where the population has never fallen below 800 individuals, and is also high in Slovenia [46] as well as neighbouring Croatia [47].

Our results represent a comparative study of a subpopulation which has hitherto received little attention from researchers. However, the brown bear is one of the best-studied mammalian species [13]. In the last two decades there has been a proliferation of genetics studies mapping populations at different geographical scales from regional $[7,8,48]$ to continental $[49,50]$. Standardised procedures have been developed for sampling and analysis in order to facilitate comparisons between studies $[46,51,52]$. Non-invasive genetic methods, especially appropriate for use with elusive species in small, endangered populations or over large areas, are now available to allow identification of individual animals, census populations and monitor migration and gene flow [13]. The potential for further work building on our study is therefore substantial. Knowledge of population size, distribution, social and sexual structure, home range and population trend on the local level as well as migration is crucial for the proper conservation and management of species within and between protected areas.

\section{ACKNOWLEDGEMENTS}

This study was supported by Structural Funds of EU Project of the Agency of the Ministry of Education, Science, Research and Sport of the Slovak Republic, Bratislava, ITMS No. 26110230078.

\section{REFERENCES}

[1] Swenson, J.E., Dahle, B., Gerstl, N. and Zedrosser, A. (2000) Action plan for the conservation of the brown bear in Europe (Ursus arctos) - Convention on the Conservation of European Wildlife and Natural Habitats (Bern Convention). Nature and Environment No. 114, Council of Europe Publishing, Strasbourg.

[2] Sommer, R.S. and Benecke, N. (2005) The recolonization of Europe by brown bears Ursus arctos Linnaeus, 1758 after the Last Glacial Maximum. Mammal Review, 35, 156-164. doi:10.1111/j.1365-2907.2005.00063.x

[3] Breitenmoser, U. (1998) Large predators in the Alps: The fall and rise of man's competitors. Biological Conservation, 83, 279-289. doi:10.1016/S0006-3207(97)00084-0

[4] Zedrosser, A., Dahle, B., Swenson, J.E. and Gerstl, N. (2001) Status and management of the brown bear in Europe. Ursus, 12, 9-12.

[5] Zachos, F.E., Ottoa, M., Unici, R., Lorenzini and R., Hartl, G.B. (2008) Evidence of a phylogeographic break in the Romanian brown bear (Ursus arctos) population from the Carpathians. Mammalian Biology, 73, 93-101. doi:10.1016/j.mambio.2007.02.007

[6] Randi, E., Gentile, L., Boscagli, G., Huber, D. and Roth, H.U. (1994) Mitochondrial DNA sequence divergence among some west European brown bear (Ursus arctos L.) populations. Lessons for conservation. Heredity, 73, 480489. doi:10.1038/hdy.1994.146

[7] Taberlet, P., Camarra, J.J., Griffin, S., Uhrès, E., Hanotte, O., Waits, L.P., Dubois-Paganon, C., Burke, T. and Bouvet, J. (1997) Noninvasive genetic tracking of the endangered Pyrenean brown bear population. Molecular Ecology, 6, 869-876. doi:10.1111/j.1365-294X.1997.tb00141.x

[8] Lorenzini, R., Posillico, M., Lovari, S. and Petrella, A. (2004) Non-invasive genotyping of the endangered Apennine brown bear: A case study not to let one's hair down. Animal Conservation, 7, 199-209. doi:10.1017/S1367943004001301

[9] Taberlet, P. and Bouvet, J. (1994) Mitochondrial DNA polymorphism, phylogeography, and conservation genetics of the brown bear Ursus arctos in Europe. Proceedings of the Royal Society B: Biological Sciences, 255, 195-200. 
[10] Kohn, M., Knauer, F., Stoffella, A., Schroder, W. and Paabo, S. (1995) Conservation genetics of the European brown bear-A study using excremental PCR of nuclear and mitochondrial sequences. Molecular Ecology, 4, 95103. doi:10.1111/j.1365-294X.1995.tb00196.x

[11] Korsten, M., Ho, S.Y.W., Davison, J., Pähn, B., Vulla, E., Roht, M., et al. (2009) Sudden expansion of a single brown bear maternal lineage across northern continental Eurasia after the last ice age: A general demographic model for mammals? Molecular Ecology, 18, 1963-1979. doi:10.1111/j.1365-294X.2009.04163.x

[12] Valdiosera, C.E., Garcia, N., Anderung, C., Dalen, L., Cregut-Bonnoure, E., Kahlke, R.-D., Stiller, M., Brandström, M., Thomas, M.G., Arsuaga, J.L., Götherström, A. and Barnes, I. (2007) Staying out in the cold: Glacial refugia and mitochondrial DNA phylogeography in ancient European brown bears. Molecular Ecology, 16, 5140-5148. doi:10.1111/j.1365-294X.2007.03590.x

[13] Swenson, J.E., Taberlet, P. and Bellemain, E. (2011) Genetics and conservation of European brown bears Ursus arctos. Mammal Review, 2, 87-98. doi:10.1111/j.1365-2907.2010.00179.x

[14] Saarma, U., Ho, S.Y.W., Pybus, O.G., Kaljuste, M., Tumanov, I.L., Kojola, I., Vorobiev, A., Markov, N.I., Saveljev, A.P., Valdmann, H., Lyapunova, E.A., Abramov, A.V., Männil, P., Korsten, M., Vulla, E., Pazetnov, S.V., Pazetnov, V.S., Putchkovskiy, S.V. and Rõkov, A.M. (2007) Mitogenetic structure of brown bears (Ursus $\operatorname{arctos}$ L.) in northeastern Europe and a new time frame for the formation of European brown bear lineages. Molecular Ecology, 16, 401-413. doi:10.1111/j.1365-294X.2006.03130.x

[15] Hartl, G.B. and Hell, P. (1994) Maintenance of high levels of allelic variation in spite of a severe bottleneck in population size: The brown bear (Ursus arctos) in the Western Carpathians. Biodiversity and Conservation, 3, 546-554. doi:10.1007/BF00115160

[16] Jamnický J. (1993) The hunt of the brown bear and European wolf in Slovakia a hundred years ago. Folia Venatoria, 23, 221-229. (in Slovak with English Summary)

[17] Hell, P. and Slamečka, J. (1999) The bear in the Slovak Carpathians and in the world. PaRPress, Bratislava, 150p. (in Slovak).

[18] Sabadoš, K. and Šimiak, M. (1981) Distribution and hunting management of the brown bear (Ursus arctos L.) in Slovakia. Folia Venatoria, 10-11, 15-35. (in Slovak)

[19] Rigg, R. and Adamec, M. (2007) Status, ecology and management of the brown bear (Ursus arctos) in Slovakia. Slovak Wildlife Society, Liptovský Hrádok, 128p.

[20] Jakubiec, Z. (2001) The brown bear Ursus arctos L. in the Polish part of the Carpathians. Polska Akademia Nauk, Kraków, 108p. (in Polish with English Summary)

[21] Straka, M., Paule, L., Ionescu, O., Štofík, J. and Adamec, M. (2012) Microsatellite diversity and structure of Carpathian brown bears (Ursus arctos): Consequences of human caused fragmentation. Conservation Genetics, 13, 153-164. doi:10.1007/s10592-011-0271-4

[22] Davison, J., Ho, S.Y.W., Bray, S.C., Korsten, M., Tam- meleht, E., Hindrikson, M., Østbye, K., Østbye, E., Lauritzen, S. E., Austin, J., Cooper, A. and Saarma, U. (2011) Late-Quaternary biogeographic scenarios for the brown bear (Ursus arctos), a wild mammal model species. Quaternary Science Reviews, 30, 418-430. doi:10.1016/j.quascirev.2010.11.023

[23] Paule, L., Krajmerová, D., Urban, P. and Adamec, M. (2006) Contribution to genetic diversity of brown bear (Ursus arctos L.) from the Western Carpathians. Výskum a Ochrana Cicavcov na Slovensku, 7, 115-121. (in Slovak with English Abstract)

[24] Janík, M., Voskár, J. and Buday, M. (1986) Present distribution of the brown bear (Ursus arctos) in Czechoslovakia. Folia Venatoria, 16, 331-352. (in Slovak with English Abstract)

[25] Kruckenhauser, L., Rauer, G., Däubl, B. and Haring, E. (2009) Genetic monitoring of a founder population of brown bears (Ursus arctos) in central Austria. Conservation Genetics, 10, 1223-1233. doi:10.1007/s10592-008-9654-6

[26] Brya, J. And Konečný, A. (2003) Fast sex identification in wild mammals using PCR amplification of the SRY gene. Folia Zoologica, 52, 269-274.

[27] Bellemain, E. and Taberlet, P. (2004) Improved noninvasive genotyping method: application to brown bear (Ursus arctos) faeces. Molecular Ecology Notes, 4, 519-522. doi:10.1111/j.1471-8286.2004.00711.x

[28] Janiga, M., Fečková, M., Korňan, J., Kalaš, M., Labudíková, I., Matiaško, K. and Londa, P. (2006) Preliminary results on genetic tracking of the Brown Bear (Ursus arctos) individuals in the Malá Fatra National Park (Slovakia). Oecologia Montana, 15, 24-26.

[29] Raymond, M. and Rousset, F. (1995) An exact test for population diferentiation. Evolution, 49, 1283-1286. doi: $10.2307 / 2410454$

[30] Weir, B.S. and Cockerham, C.C. (1984) Estimating Fstatistics for the analysis of population structure. Evolution, 38, 1358-1370. doi:10.2307/2408641

[31] Robertson, A. and Hill, W.G. (1984) Deviations from Hardy-Weinberg proportions: Sampling variances and use in estimation of inbreeding coefficients. Genetics, 107, 703-718.

[32] Guo, S.W. and Thompson, E.A. (1992) Performing the exact test of Hardy-Weinberg proportion for multiple alleles. Biometrics, 48, 361-372. doi:10.2307/2532296

[33] Goldstein, D.B. and Schlotterer, C. (1999) Microsatellites: Evolution and applications. Oxford University Press, Oxford.

[34] Kimura, M. and Crow, J. (1964) The number of alleles that can be maintained in a finite population. Genetics, $\mathbf{4 9}$, 725-738.

[35] Valdes, A.M., Slatkin, M. and Freimer, N.B. (1993) Allele frequencies at microsatellite loci: The stepwise mutation model revisited. Genetics, 133, 737-749.

[36] Di Rienzo, A., Peterson, A.C., Garza, J.C., Valdes, A.M., Slatkin, M. and Freimer, N.B. (1994) Mutational processes of simple-sequence repeat loci in human populations. Proceedings of the National Academy of Sciences 
of the United States of America, 91, 3166-3170. doi:10.1073/pnas.91.8.3166

[37] Marshall, T.C., Slate, J., Kruuk, L.E.B. and Pemberton, J.M. (1998) Statistical confidence for likelihood-based paternity inference in natural populations. Molecular Ecology, 7, 639-655. doi:10.1046/j.1365-294x.1998.00374.x

[38] Saitou, N. and Nei, M. (1987) The neighbor-joining method: A new method for reconstructing phylogenetic trees. Molecular Biology and Evolution, 4, 406-425.

[39] Zedrosser, A., Støen, O.-G., Sæbø, S. and Swenson, J.E. (2007) Should I stay or should I go? Natal dispersal in the brown bear. Animal Behaviour, 74, 369-376. doi:10.1016/j.anbehav.2006.09.015

[40] Fernández, N., Selva, N., Yuste, C., Okarma, H. and Jakubiec, Z. (2012) Brown bears at the edge: Modelling habitat constrains at the periphery of the Carpathian population. Biological Conservation, 153, 134-142. doi:10.1016/j.biocon.2012.04.013

[41] Find'o, S., Skuban, M. and Koreň, M. (2007) Brown bear corridors in Slovakia. Carpathian Wildlife Society, Zvolen.

[42] Pérez, T., Naves, J., Vázquez, J.F., Seijas, J., Corao, A., Albornoz, J. and Domínguez, A. (2010) Evidence for improved connectivity between Cantabrian brown bear subpopulations. Ursus, 21, 104-108. doi:10.2192/09SC018.1

[43] Waits, L.P., Taberlet, P., Swenson, J.E., Sandegren, F. and Franzén, R. (2000) Nuclear DNA microsatellite analysis of genetic diversity and gene flow in the Scandinavian brown bear (Ursus arctos). Molecular Ecology, 9, 421-431. doi:10.1046/j.1365-294x.2000.00892.x

[44] Tallmon, D.A., Bellemain, E., Swenson, J. and Taberlet, P. (2004) Genetic monitoring of Scandinavian brown bear effective population size and immigration. Journal of Wildlife Management, 68, 960-965. doi:10.2193/0022-541X(2004)068[0960:GMOSBB]2.0.C $\underline{\mathrm{O} ; 2}$

[45] Paunović, M. and Ćirović, D. (2006) Viability increase and recovery of brown bear (Ursus arctos L. 1758) population in northeastern Serbia-A Feasibility Study. Faculty of Biology. University of Belgrade, Belgrade.

[46] Skrbinšek, T., Jelenčič, M., Waits, L.P., Potočnik, H., Kos, I. and Trontelj, P. (2012) Using a reference population yardstick to calibrate and compare genetic diversity reported in different studies: An example from the brown bear. Heredity, 109, 299-305.

[47] Kocijan, I., Galov, A., Cetković, H., Kusak, J., Gomerčić, T. and Huber, Đ. (2011) Genetic diversity of Dinaric brown bears (Ursus arctos) in Croatia with implications for bear conservation in Europe. Mammalian BiologyZeitschrift fur Saugetierkunde, 76, 615-621.

[48] De Barba, M., Waits, L.P., Garton, E.O., Genovesi, P., Randi, E., Mustoni, A. and Groff, C. (2010) The power of genetic monitoring for studying demography, ecology and genetics of a reintroduced brown bear population. Molecular Ecology, 19, 3938-3951. doi:10.1111/j.1365-294X.2010.04791.x

[49] Paetkau, D., Waits, L.P., Clarkson, P., Craighead, L., Vyse, E.R., Ward, R. and Strobeck, C. (1998) Variation in genetic diversity across the range of North American brown bears. Conservation Biology, 12, 418-429.

[50] Tammeleht, E., Remm, J., Korsten, M., Davidson, J., Tumanov, I., Saveljev, A., Männil, P., Kojola, I. and Saarma, U. (2010) Genetic structure in large, continuous mammal populations: The example of brown bears in northwestern Eurasia. Molecular Ecology, 19, 5359-5370. doi:10.1111/j.1365-294X.2010.04885.x

[51] Aarnes, S.G., Bellemain, E., Eiken, H.G. and Wartainen, I. (2009) Interlaboratory comparison of genetic profiles of brown bears from Sweden (Laboratoire d'Ecologie Alpine) and Norway (Bioforsk Svanhovd). Bioforsk Report, 4, 133.

[52] Karamanlidis, A.A., De Barba, M., Georgiadis, L., Groff, C., Jelinčić, M., Kocijan, I., Kruckenhauser, L., Rauer, G., Sindičić, M., Skrbinšek, T. and Huber, D. (2009) Common guidelines for the genetic study of brown bears (Ursus arctos) in southeastern Europe. LCIE, Athens. 